\title{
Assessment of Group Tasks as a Decolonial Pedagogy in University Classrooms
}

\author{
Bunmi Isaiah Omodan
}

School of Education Studies, University of the Free State, South Africa

Received July 27, 2020; Revised September 2, 2020; Accepted September 29, 2020

\section{Cite This Paper in the following Citation Styles}

(a): [1] Bunmi Isaiah Omodan , "Assessment of Group Tasks as a Decolonial Pedagogy in University Classrooms," Universal Journal of Educational Research, Vol. 8, No. 11, pp. 5479 - 5488, 2020. DOI: 10.13189/ujer.2020.081151.

(b): Bunmi Isaiah Omodan (2020). Assessment of Group Tasks as a Decolonial Pedagogy in University Classrooms. Universal Journal of Educational Research, 8(11), 5479 - 5488. DOI: 10.13189/ujer.2020.081151.

Copyright $\bigcirc 2020$ by authors, all rights reserved. Authors agree that this article remains permanently open access under the terms of the Creative Commons Attribution License 4.0 International License

\begin{abstract}
The decolonisation of university classrooms has been of significant concern in recent times. Many decolonial strategies have been recommended in bodies of existing literature, still, none has considered the intricacies of collaborative group tasks as a strategy to decolonise classroom hegemony. This study examined the use of group tasks as a decolonial strategy, lensed through Transformative Paradigm and Participatory Action Research as a research design. This study adopted students' reflection to collect data from ten students randomly selected among the 266 students who were given individual and group tasks assessment, respectively. The collected data was analysed using Socio-thematic Analysis to interpret and make sense of the responses from the students. The study revealed that collaborative group task enhances students' conventional development and unity among the students towards productivity, in addition to increasing their conflict management skill. Further findings showed that students' laziness and time consumption were found to be the hindrance to the smooth actualisation of group work among students in the university classrooms. This study recommends that efforts be put in place to ensure that group tasks are monitored and that concerned authorities; lecturers and university academic planners must ensure that students are taught how to make effective use of their time.
\end{abstract}

Keywords Group Tasks, Decolonial Pedagogy, University Classrooms, Social Constructivism

\section{Introduction}

The trajectory of the knowledge economy is a devotion that is presently driving the tenets of development in western nations. That is, the adoption of the knowledge economy is, no doubt, a good agenda for any country, state, local and community systems that want to meet up with international development standards. No wonder, the reality of the knowledge economy as stated by World Bank and Organisation for Economic Cooperation and Development (OECD) was recommended as a yardstick for global stability and quality development stratum for humanity (OECD, 1996). This idea was conceptualised as economic progress, development and transformation of any entity that depends on quality knowledge and research productivity (Hadad, 2017). That is, the economy in such space depends on quality inputs, process and output of quality knowledge. The adoption of knowledge-economy by the government of South Africa is unequivocally a right step in the right direction (Blankley \& Booyens, 2010; Groenendaal, 2018). This, in my argument, means that knowledge is now recognised as one of the quintessential capitals responsible for economic growth and development in South Africa. However, the idea of knowledge economy cannot exist in abstract, the sustainability of such idea depends on how the country through its universities can reconstruct its pedagogical space where the younger generation can be exposed to the teaching and learning process that inbuilt critical thinking skill, problem-solving skill, collaborative knowledge construction and innovative skill. 
To ensure these, there is a need to redirect the teaching and learning space of universities in South Africa from traditional/rote/colonised teaching and learning process to meet up with 21st-century pedagogical standards where university students will be trained, exposed and made to understand the practicality of the world of development and productivity. It was observed that many teaching and learning spaces in universities are still wallowing in the illusion of what I tagged colonised teaching and learning system; where the lecturers are perceived as the only bank of knowledge (Raja \& Najmonnisa, 2018; Tularam \& Machise, 2018). In such a pedagogical system, students are denied the opportunity to contribute to knowledge generation process and made to believe and follow instructions without questions while being denied democratic involvement and participation in the things that concern them. Omodan (2019a) holds that it is subjective and discourage students from becoming critical problem solvers in the future. Besides, such coloniality discourages knowledge generation, knowledge acquisition, knowledge diffusion, and the exploitation of knowledge towards nation-building (Peters \& Humes, 2003). Hence, to avert these deficiencies in the future of human capital, the current system must be decolonised to pave the way for a pedagogical process that encourages self-esteem, self-determination, self-efficacy and co-operative creativity among students for a better and sound economy dispensation (Omodan \& Dube, 2020; Omodan, 2020a).

The introduction of social groups in classrooms which is a step in the right direction can be linked to what Vygotsky (1986) tagged as a process of socially constructing knowledge. Such sociality is described as knowledge based on human social relationships (McMahon, 1997). Omodan and Tsotetsi (2020) also viewed the product of such an approach as the knowledge generated from a discussion and interaction with environmentalism. That is, true knowledge is dependent on social reality, which will not only be limited to the members of the group but also the nature of their environment. Kim (2014), concluding on the discussion, posits that the sociality of the members of society cannot be detached from their social and cultural reality. From these concepts, one can see that the introduction of group tasks among students can go a long way in exposing them to healthy self-esteem, self-determination, self-efficacy and co-operative creativity which will enhance their academic performance in addition to their productivity in the university, and the nation at large. Corroborating this notion, Kasim (2015) in his research, found out that social group work is better than traditional teaching and enhances students' achievement. Brame and Biel (2015) described this kind of sociality in the classroom as involving both formal and informal activities where students learn by interaction and an effective teaching-learning process in classrooms. In the same vein, Johnson, Johnson and Smith (2014) is of the view that a collaborative approach among students when working in a group characterised by positive interdependence, where students believe that their input produces better group performance. One can then deduce that knowledge production becomes better when students are made to work in groups. This is not far-fetched from an adage that says "two heads are better than one." From the arguments above, one can perceive that the space of collaborative knowledge construction in the form of grouping, is fundamental to students' performance and their personal development. Therefore, there is a need to decolonise the traditional pedagogical process in university classrooms through group tasking.

\subsection{Decoloniality as a theoretical Framework}

Decoloniality as an epistemic site was born out of the need to extricate the previously colonised generation from the mental clutches of coloniality. That is, the realisation that our present world is an asymmetrical world order that is sustained not only by colonial matrices of power but also by the pedagogies and epistemologies of equilibrium that continue to produce alienated Africans who are indoctrinated into hating the Africa that produced them and liking the Europe and America that rejected them (Ndlovu, 2013). To further understand the rudiments of decoloniality, Ndlovu-Gatsheni (2015) asks fundamental questions into the main fabric of decolonial epistemology; how can a 'dismembered' people be 're-membered'? How can they re-launch themselves from the world of 'non-being' into the world of' being'? How can they recapture their lost land, power, history, being, language and knowledge? These questions border mostly on liberation from the old ways of doing things, in the form of transformation. Ngugi wa Thiong'o (1986) sees decoloniality as a quest for liberation and self-understanding after centuries of suffering dismemberment and alienation. Ndlovu-Gatsheni (2013) also reiterated that decoloniality is a necessity for dismembered people to re-launch themselves into the world. Fanon (1968) in his post-colonial treatise writes that decoloniality is a deliberate attempt to create new forms of life, and subvert the logic of repetition that is devoid of dynamism. Therefore, both Quijano (2007) and Ndlovu-Gatsheni (2015) believe that decoloniality attempts to make sense of what is happening and being experienced in particular geopolitical sites that were previously the recipients of the negatives of modernity known as coloniality.

Coloniality, as claimed by Ndlovu-Gatsheni, is peculiar to geopolitical sites, but in my argument, they also exist in university classrooms. The 21st-century classroom is overwhelmed by the leftovers of coloniality which have become unavoidable and, therefore, affect the quality of indigenous knowledge production in the university system (Omodan \& Dube, 2020). This further confirms the view that the space of sociality, democratic socialisation, and ingenious knowledge construction are faced with the problems of subjectivism. This may not be unconnected with the effect of Bantu education experienced in the history of South Africa (Musitha \& Mafukata, 2018; 
Omodan, 2019a). Parker, Smith and Dennison (2017) in their study described teacher supremacy in the classroom as a colonial legacy responsible for the undemocratic and dependency in the process of knowledge production. From this, one can say that classroom decoloniality cannot be separated from the methodological relationships that exist between lecturers and students. Not only that, but it is also connected to the extent to which an enabling environment is created for the students to be able to jointly construct knowledge by themselves and for themselves, though, under the guardian of a facilitator or lecturer (Adebola, 2020). This further reinstates the quest for scholastic dependency in university classrooms (Ashcroft, Griffiths, \& Tiffin, 2003).

This theory, therefore, is relevant in the sense that, collaborative knowledge construction can never be taken away from classroom decoloniality because it gives students their space to think and make sense of situations without being subjected to believing in lecturers' ideas alone. This is to say that the process of classroom decoloniality is to ensure that the process of knowledge construction is not limited to the powerful (lecturers) alone but should be extended to the less-powerful (students). Besides, when there is total recognition, engaging in classroom collaboration creates some sense of belongings in the students and enhances their productivity (Adebola, Tsotetsi \& Omodan, 2020). This process will eliminate inferiority complex in students, not only that, but they will also feel included as counterparts in the process of knowledge generation (Rodney, 2012). In furtherance to my claim, the findings of Leslie, Cimpian, Meyer and Freeland (2015) showed that students, when exposed to group work as a collaborative knowledge construction process, it helps them to think critically and challenge the status quo. However, being empowered to challenge the asymmetric power is the hallmark of decoloniality and liberation. Hence, a decolonised classroom could be likened to a decentralised teaching-learning system where the lecturer or student is not the sole knowledge producer by ensuring active collaborative and engagement among the students. When this is done, the process of knowledge generation in the university system can be said to be decolonised.

\subsection{Research Question}

To respond to the above problem, the following general question was raised to pilot the study:

- How can classroom group tasks be used as a tool to decolonise the pedagogical space in university classrooms?

\subsection{Objectives of the Study}

To answer the above general question, the following research objectives are raised to guide the study:

- The objective was to investigate the perception of students towards collaborative (group) task in the university classrooms.

- The objective was to examine the weakness of collaborative (group) task as a decolonial pedagogy in university classrooms.

\section{Methodology}

In the words of Scotland (2012), research methodology is a process and procedures, principles and assumptions in a specific approach to enquiry. Research methodology (as demonstrated in figure 1) typically comprises the identification of paradigm, research design, methods of implementing research plans and the phases of the adopted techniques (Kothari, 2004, Igwenagu, 2016; Omodan, 2019b). To further understand this, the methodological model below was made by the researcher to guide the research process.

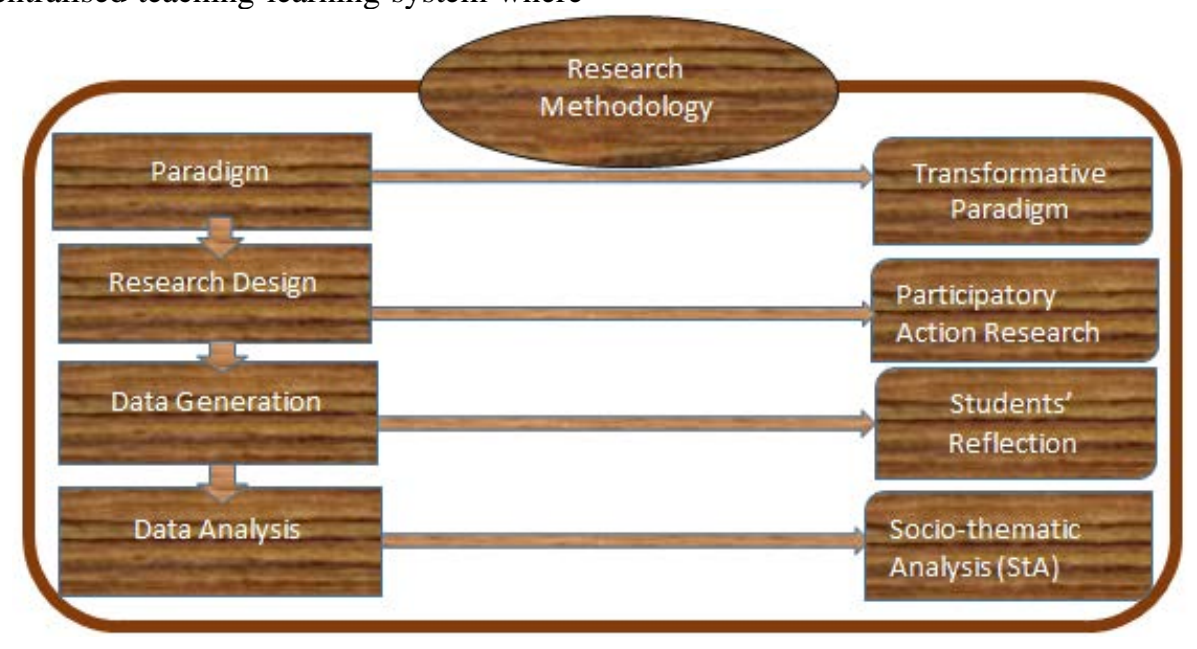

Figure 1. Methodological Plan 


\subsection{Paradigm and Research Design}

This study is lensed with Transformative Paradigm (TP) and it is appropriate because it complements the decoloniality agenda by opening ways for students to jointly generate knowledge and get into themselves to transform their predicament (classroom tasks). The choice of this paradigm also lies in its ontological and epistemic stance rooted in the social nature of classroom reality (Chilisa, 2011). Transformative paradigm is not only suitable for this study because of its quest for academic freedom (Scott \& Usher, 2011) but it is a paradigm that preaches emancipation by challenging social phenomenon (Omodan, 2020b). In order to complement this, Participatory Action Research (PAR) was adopted as a research design for the study. PAR is relevant because it is a kind of design that appreciates the participatory process in research. It involves action, inclusivity and discouragement of power differentials among the participants (Khan \& Chovanec, 2010). The major assumption of PAR is that it ensures that the people faced with the problem(s) are actively and indiscriminately involved in the process of finding a solution to their problems (Zuber-Skerritt, 2015) which in this study is to emancipate, transform and decolonise the practical classroom space. The student of a particular module amount to 266 students was involved. The process of data collection and their involvement are explained below.

\subsection{The Participants and the Process of Data Collection}

The study derived its knowledge from students' reflection. Students' reflection according to university social language in South Africa is when a student gives accounts of what has happened, about a particular event and how he or she feels about it. If it is from a negative reflection, such student also suggests what he or she thinks could be used to mitigate it based on previous experience. In this case, the researcher is a lecturer in the selected university, teaching LSPT4705, a continuation of LSPT3605, 4th and 3rd-year modules respectively. I gave the students two different individual tasks at two different times and I also gave two different group tasks differently at two separate occasions within a one-month interval. The instruction on the individual classroom tasks was that they must make sure they study the questions, interpret them and present their answers to the question. On the group task, they are meant to form a group of at least five members and a maximum of ten members among themselves. That is, each group contains not less than five members and not more than ten members. With an instruction that all of them must participate from the question interpretation stage to the answer production stage. The assessment is made compulsory because all the assessments form part of their semester marks (continuous assessment). At the end of this process, ten students were randomly selected to give their reflections on all the activities we have done, ranging from the two individual and group tasks. Their reflections, therefore, forms the data for the study.

\subsection{Data Analysis and Ethical Consideration}

In order to make sense of the data, the study adopted Socio-thematic Analysis (StA). This method of data analysis was developed by Omodan (2019b) as capable of interpreting people's sociality. This method, according to him, combined the principles of Braun \& Clarke's (2006) six steps of doing thematic analysis and the use of conversational analysis described by Nordquist (2019 p. 2) "as doing things with words to perform social actions such as describing, agreeing, questioning, and talking." This is an instrument that is best to interpret the sociality involved in data that has been broken down into themes (Omodan, 2020b). This was implemented to respond to the objectives of the study, which were already in two different themes. That is, the data collected were studied, coded, broken into suitable themes and sub-themes, reviewing the themes, identifying and naming the themes and employ conversationality to make sense of the data during interpretation and analysis stage. That is, all the identified themes were subjected to a sociality test to produce unaltered meanings. The issue of research ethics was keenly followed and respected because it is very important to protect both the researcher and the co-researchers from any potential harm (Fleming \& Zegwaard, 2018). To ensure this, all the participants were given the freedom to withdraw from the process should they feel uncomfortable with the process, and they were assured that their identities would be protected before, during and after the process. They all agreed to remain anonymous even in the data interpretation stage. Therefore, they were represented with pseudonyms such as S1 for student number one, S2 for student number 2, in this range until S10 for student number 10 . The data is presented below.

\section{Presentation and Analysis of Data}

This session presents the data gathered from the participatory research process, using student perceptions of group tasks emanating from their various activities in class. The data is presented in accordance with the objectives of the study. The objectives were divided into analysis of sub-themes (see table 1).

Table 1. Thematic Representation of Data Based on the Research Objectives

\begin{tabular}{|c|c|}
\hline Objectives & Analysis of Sub-themes \\
\hline $\begin{array}{c}\text { 1. The perception of students } \\
\text { towards collaborative } \\
\text { (group) task }\end{array}$ & $\begin{array}{c}\text { Student conventional } \\
\text { development } \\
\text { Enhancement unity towards } \\
\text { productivity } \\
\text { Conflict Management. }\end{array}$ \\
\hline $\begin{array}{c}\text { 2. Possible weakness of } \\
\text { collaborative (group) tasks in } \\
\text { university classrooms }\end{array}$ & $\begin{array}{c}\text { Enhancement of laziness in } \\
\text { students } \\
\text { Time consumption. } \\
\end{array}$ \\
\hline
\end{tabular}




\subsection{The perception of Students towards Collaborative (group) Tasks}

\subsubsection{Student conventional development}

From the data generated, evidence suffices that the students are happy to be involved in collaborative group tasks in the form of assignments, among others. This is not far from Monk-Turner and Payne's (2005) submission that students feel secure and active when given group assignments because it develops relationship skills in them. In other words, the implementation of group work among students brings many skills development such as critical thinking skills, relationship skills, interpersonal skills, and communication skills. See the following participant statements;

S9: I prefer collaborative group work, how I perceive the whole concept is that when working in groups you can share ideas and views with other students, to get an insight on how other students tackle problems and also how they go about when facing the challenges that you face when working alone.

S10: In group work, people's levels of understanding are not the same and having group members that support each other to understand the content makes life for other students easier, this also includes making examples and sharing more information or insight.

From the first statement, the student prefers to work in a group because it enables them to share ideas and views in the process of generating knowledge. This is important to the students because it allows them to get into themselves, learn from one another's experience in the process of solving and or generating knowledge. In the same vein, the second participant also shares the same perception by reiterating that the coming together of other students enable them to support one another and understand the content of the group work. This is by S10 who agrees that because students do not have the same level of understanding and need to be supported by one another. The following participants' statements also follow suit;

S1: Group work develops us towards a common goal, because, working in groups, to me, means gaining more insightful ideas, shared arguments, challenging yourself when given a role, helping each other, problem and conflict- solving; gaining skills like confidence, responsibility, patience, tolerance and reliability.

S1: I prefer collaborative group tasks because if we do assessments in groups, I can at least try to gain more from other friends, I mean other group members and me can finish what we have started.

The participant, S1, confirms the benefit of working together as a group by saying it develops them towards working as one, to achieve a common goal. This is because it gives them opportunity to interact, share ideas, engage in arguments, gain more confidence and able to challenge perceived inadequacies. Not only that, but it also develops the students in the area where they have to be tolerant of one another, taking responsibility, and be reliable. All of these border more on their development. The notion above is supported by $\mathrm{S} 1$ who says that group tasks help them to gain more knowledge from other students.

From the analysis based on student conventional development, it was discovered that all participants are in love with the use of group work as an assessment task for them. This is seen as being significant to student development in all areas such as; social skills, relational skills, ability to help and support each other, among others. The finding aligns with Chandra (2015) who wrote that collaborative methodology enhances student development towards performance. The conclusion of Laal and Laal (2012) also show that group work makes students focus more on achievement and personal development, rather than competition. From this argument, one can see that the use of group work in the form of assessment tasks among university students is synonymous with classroom decoloniality because it brings them together, helps them gain knowledge and confidence that can enable them to challenge the existing status quo which is the hallmark of the decolonial agenda in classroom ecology (Leslie et al., 2015).

\subsubsection{Enhancement of unity towards productivity}

The process of bringing people together to solve a particular problem most especially in the classroom is very fundamental to the teaching of unity in diversity. This also helps students to gain more problem-solving skills that will help them navigate themselves in the corporate environment. Omodan and Tsotetsi (2020) are of the view thatcollaborative knowledge construction enhances oneness, unity and love among students. This also suffices in the data collected. See the below statements:

S4: Working in groups prepares us (teachers) for the world of work and learning how to effectively work with others and respect their viewpoints even if you don't agree with it.

S4: I prefer working in groups. This is simply because there is more than one individual gathering or putting together a task. People have different perspectives and engaging with others widens a person's way of thinking towards a task at hand.

S5: Group work is less time-consuming as the task can be divided to suit the number of group members and can be done simultaneously. Ideas are shared and sometimes how you may have understood the task can be altered for the best when in discussion within a group.

S5: This allows people to see tasks in different views from their own giving a better understanding.

S6: Yes, I prefer collaborative (group) task as it enables participation, sharing and decision-making and understanding of one's weaknesses. 
According to S4, working together brings them together as one to achieve their tasks. While doing this, it helps them to learn how to work in a group, respect others' views and also promotes how to react and think individually to make meaningful contributions to the group's development. In the same vein, S4 says that when many people gather together, it widens their thinking abilities towards achieving the task at hand. From this, one can see that making people (students) work together is synonymous to teaching them how to live, function and socialise in the larger society where there are diverse opinions, perspectives and ways of doing things. S5 also supported the idea and reiterated that group tasks enable people to gain a better understanding of issues when they listen to different views coming from their group members. Not only that, but S5's statement also shows that when tasks are done in a group, it saves more time, that is, it is also less time-consuming. From the social standpoint, this means that they can finish their task and submit in time. This, in turn, will create in them how to effective time management, most especially in their respective workplaces. The statement from S6 also indicated that group work enables them to be participatory in nature and to understand their weaknesses. When all these are coming as a revelation from the students, it is an indication that there is universality even in the face of differences and their ability to manage it shows they have gained knowledge, not only from the content of the task, but the knowledge and skill needed in the world of work are also inculcated into them.

The findings from the enhancement of unity towards productivity show that the implementation of group tasks among university students bring them together as one towards their productivity. This finding is in line with Collin (2003) who noted that the involvement of students in a collaborative project does not only enhance unity but also creates in them the skills needed to survive in life. In the same argument, Piatt-Jaeger (2011) also confirms that the community of individuals in the schools significantly enhances youth preparedness for the future. Conclusion on this, Quan-Baffour (2014) explains that social activities in the teaching-learning process brings love and unity among students and thereby enables them to emancipate themselves. By doing this, one can say that unity among students where they can construct knowledge, think critically, and solve their problems by themselves is an indication of self-transformation, emancipation and decoloniality. This is, however, in a bid to corroborate what Ndlovu-Gatsheni (2015) means when he agrees that decoloniality is meant to re-member the dis-membered people into the word of "being".

\subsubsection{Conflict management}

The issue of conflict, resolution and its management is very fundamental in the teaching-learning community, most especially university classrooms. It becomes imperative in a diversified classroom like South Africa, with many recognised diversities. Therefore, engaging in the teaching and learning method that will increase the level of conflict management skill among the students is not out of place. The trajectory of group work also borders on the fact that when students are given group work, they end up gaining knowledge and skill on how to manage their differences because where two or more people are gathered, conflict is inevitable. The skill gained in the process of group work was mentioned by the following participants:

S3: As much as people like myself prefer to work alone we do well in groups also because we understand the importance of group work and it makes me acquire the skills necessary to ensure harmony amongst group members.

S2: I prefer group work. Working with those you have chosen makes the process smoother even if conflicts arise, we can work it out quickly.

S9: Collaborative work also plays an important role in improving one's communication and leadership skills because at one point you become the group leader and have to give direction to other students mostly when there is conflict.

From the first statement, participant S3 confirms that working together among people contributes to his development by learning the importance of group work, among which the spirit of harmony is. That is while working together, it teaches them to put their differences apart and embrace one another as one. This was also upheld by participant S2 who said that although working together also brings some conflictual tendencies, they can resolve it and move on. This is evidenced in the way they learn how to cope with one another and manage their differences. From S9's statement, we can deduce that collaborative work gives one some leadership acumen among which is the ability to manage conflict most especially when you are made the leader of such a group. As a group leader, you should possess conflict management skills. In order to solve issues among themselves, they help to tackle the problems relating to their task. This is shown in the comments below:

S6: During group work, we make mistakes, and we rectify one another's mistakes before our task can be submitted.

S2: I prefer group work because the process makes me understand how to live with strangers without fighting.

This action, as mentioned by participant S6, shows that they are motivating themselves towards their productivity. That is, they are helping one another to perform well. And not only that, the resultant effect is that it brings them together as one, irrespective of their backgrounds, differences and ways of life. This is why participant S2 refers to them as strangers. According to S2, working together help him to understand people and how to live with them in harmony. 
Conflict management reveals that collaborative tasks, in the form of group work among university students, make the students gain conflict management skills. This is evidenced in their revelations as mentioned above. This is because, when working together, they have no choice than to tolerate one another even in the face of diversities. This enables them to achieve their aims and objectives as a group and also make themes acquire conflict management skills ahead of their world of work. This justifies Atieno, Paul and Yego's (2016) argument that schools that adopt a collaborative style of engagement have less experience with the problems of academic unrest in Kenya. In the same vein, Kalagbor and Nnokam (2015) also supported this and include that collaboration is the best approach to classroom harmony among students. Therefore, this finding holds that when students are exposed to group work, they are likely to understand themselves and transform themselves from the shackles of conflict and brigandage.

\subsection{Possible Weakness of Collaborative (group) Tasks in University Classrooms}

\subsubsection{Enhancement of laziness in students}

As good as group work sounds among students, many shortcomings are attributed to it, among which is an enhancement of laziness among students. Laziness, as discussed here, is manifested in different ways to different students. The following statements from the participants confirm my argument. See below:

S8: Also, it is tiring because some group members don't want to do anything; others have to beg them to do their parts. Furthermore, we end up completing other members' work so as not to fail the given task.

S9: It makes some of us lazy, and I, for one, tend to lean on other students when I feel lazy or have too much workload.

S10: It also depends on the kind of people you have in your group because some members may not contribute to activities.

Participant S8 affirms that group work is tiring, and not only that, some group members are fond of not doing their ascribed tasks thereby making the work more cumbersome for other group members who are serious with their studies. S9, who is on the same page with S8, supports his/her concern by saying that group work makes some of them lazy because they know that even if they did not participate, other members are there to rescue the group by doing the work. S10 also reiterated that some members in the group will not normally contribute towards the group task. From social understanding, this may be as a result of the fact that some members are not finding it easy to cope well amid people and or that such member believes that whether or not he or she contributed, the group work will be submitted and all of them will be rewarded based on what the available group members can do. The statements below supported my arguments above;
S1: But initially, I prefer working alone, simply because in groups there are people that don't want to work, when the results are bad they point fingers and when results are good they take the credit.

S2: You sometimes find yourself having to collaborate with people who are lazy to work; also some people will do the work just because they have to without putting more focus and understanding of the given work.

S3: Some members put little effort and do things lavishly and in turn, submit copied and pasted work.

The statement from S1 shows that some members do not want to work, and they even ended up blaming other group members for their failures. Not only this, as mentioned by S2, there are group members who are involved in the group work but do not put in enough effort because they think others will do it for them. S2 even alleged that most times, they will only be present just because they have to, not because they are ready to make any contribution. In the case where the group work is shared among members, some of the members ended up submitting "copy and paste" work because of their unwillingness to make good contributions.

This finding from the enhancement of laziness in students showed that group work has its advantages and disadvantages as well. Among the disadvantages, it was revealed that it leads to laziness among some students. This is not a strange sight because there are bound to be individual differences among students; some are good when it comes to group discussions while others prefer working within their space without people around. Not only that, socially, some people, according to Macgregor's theory $\mathrm{X}$ and $\mathrm{Y}$ are inherently lazy and need to be told or coerced to do the needful (McGregor, 1960). The finding is also supported by the conclusion of Andrews and Rapp (2015) that collaborative work leads to unequal productivity when group members unequally contribute towards the actualisation of the task at hand. The finding of Andrews and Rapp (2014) also showed that sometimes, students rely on the contribution of their partners, even when such contributions are incorrect. The students' laziness and unwillingness to contribute to the development of group work is one of the challenges and or weakness of collaborative group tasks among university students.

\subsubsection{Time consumption}

The issue of time has been one of the important aspects of teaching and learning, including when group tasks are given to students. It usually comes with a time limit to which the students/group must submit their task for assessment. In this case, the participants see group work among themselves as time-consuming. That is, the period to which the task is to be done is a waste of their time. This was indicated in the participants' statements below:

S6: Even if its time-consuming when consulting one 
another, we still manage our time to meet up.

S7: My perception with group tasks is that they are time-consuming because group members have to meet to complete the tasks.

S4: I also think that my weakness is to put myself under the pressure of long time group discussions by completing tasks when they are closer to the due date, so, I end up not coping well.

Revelation coming from these participants showed that one of the challenges confronting the implementation and or the use of a collaborative group task is time-consuming. This was reflected in the statement of participant S6 that the period to which they have to gather themselves and perform the group activities is time-consuming. In my view, this may be because students are faced with various issues in their academic life which may differ from student to student. This is also supported by the revelation of participant $\mathrm{S} 4$ that group time is time-consuming because of the time they have to create for themselves to meet to perform their activities. On the perception of participant S4, the issue of time gives more pressure. This may be as a result of the fact that they need to adjust themselves from their original schedule to be able to meet up with their group work.

The finding from time consumption showed that one of the challenges or weakness of collaborative group tasks among university students is that group tasks consumes more time. This, according to them, propels more pressure for students because they must meet up with deadlines which may have affected their schedules. This findings is inconsistent with many pieces of literature around positive time management among students (Khanam, Sahu, Rao, Kar \& Quazi, 2017; Nasrullah \& Khan, 2015). This shows that needs to be recognised as a huge problem facing the implementation of group tasks in university classrooms. This weakness may affect students' commitment, performance and personal development (Bertsch, Ondracek, Saeed, Stone, Erickson, Opdahl, Fitterer \& Magana, 2017). The findings of Omodan and Tsotetsi (2020) affirms that time not used effectively discourages objective thinking among students. This, in my argument, is an obstacle to decoloniality in the 21st-century classrooms. This, however, means that the issue of time is a challenge to group tasks implementation in university classrooms.

\section{Conclusion, Limitation and Recommendations}

The study reconfirms the importance of collaborative knowledge construction in the form of group tasks as one of the ways to inject the decoloniality agenda in university classrooms. This was achieved with the use of transformative paradigm and participatory action research design which encourages people facing a problem to come together and transform their predicament jointly. From the findings as reported above, it is evidenced that the use of collaborative group tasks enhances students' conventional development into the world of work, it also enhances unity among students towards productivity; and above all, it increases their skill towards conflict management. The use of collaborative group task is very favourable to students' life but then, students' laziness and time consumption were found out to be the limitations that could hinder the smooth actualisation of group work among students in university classrooms. Banking on these limitations, it is, therefore, recommended that concerted efforts should be put in place by lecturers and students to ensure that group tasks are monitored in and ensure that all the group members participate actively in group activities. Secondly, there is the need for concerned authorities, lecturers and university academic planners to ensure there that students are taught how to make effective use of their time in order to adjust to any academic contingencies.

\section{REFERENCES}

[1] Adebola O. O, Tsotetsi, C. T., \& Omodan B. I. (2020). Enhancing students' academic performance in university system: The perspective of supplemental instruction. International Journal of Learning, Teaching and Educational Research, 19(5), 217-230. https://doi.org/10.2 6803/ijlter.19.5.13.

[2] Adebola, O. O. (2020). The use of supplemental instruction to enhance the academic performance of first-year students in a university. M.Ed thesis, University of the Free State.

[3] Andrews, J. J., \& Rapp, D. N. (2015). Benefits, costs, and challenges of collaboration for learning and memory. Translational Issues in Psychological Science, 1(2), 182191.

[4] Andrews, J. J., \& Rapp, D. N. (2014). Partner characteristics and social contagion: Does group composition matter? Applied Cognitive Psychology, 28, 505-517. http://dx.doi.org/10.1002/acp.3024.

[5] Ashcroft, B., Griffiths, G., \& Tiffin, H. (2003). The empire writes back: Theory and practice in postcolonial literatures. New York: Routledge.

[6] Atieno, M. A., Paul, K., \& Yego, E. (2016). Collaboration conflict management strategy: A solution to secondary schools' unrests in Kenya. International Journal of Trend in Research and Development, 3(6), 203-207.

[7] Bertsch, A., Ondracek, J., Saeed, M., Stone, C., Erickson, K., Opdahl, K., Fitterer, J., \& Magana, S. (2017). Free time management of university students in the USA. GE-International Journal of Management Research, 5(8), 63-91.

[8] Blankley, W. O., \& Booyens, I. (2010). Building a knowledge economy in South Africa.

South African Journal of Science, 106 (11/12). 1-6. http://d 
x.doi.org/10.4102/sajs.v106i11/12.373

[9] Brame, C. J., \& Biel, R. (2015). Setting up and facilitating group work: Using cooperative learning groups effectively. Retrieved [todaysdate] from http://cft.vanderbilt.edu/guides -sub-pages/setting-up-and-facilitating-group-work-using-co operative-learning-groups-effectively/.

[10] Braun, V., \& Clarke, V. (2006). Using thematic analysis in psychology. Qualitative Research in Psychology, 3(2), 77101.

[11] Chandra, R. (2015). Collaborative learning for educational achievement. Journal of Research \& Method in Education, 5(2), 1-5.

[12] Chilisa, B. (2011). Indigenous research methodologies. Thousand Oaks: Sage.

[13] Collin, M. A. (2003). The toolbox project: Tools for living tools for life. http://toolboxproject.org/resources.html 15/07/2020.

[14] Fanon, F. (1968). The wretched of the earth. New York: Grove Press.

[15] Fleming, J., \& Zegwaard, K. E. (2018). Methodologies, methods and ethical considerations for conducting research in work-integrated learning. International Journal of Work-Integrated Learning, 19(3), 205-213.https://files.eric. ed.gov/fulltext/EJ1196755.pdf

[16] Groenendaal, H. V. (2018). Government to invest R7,8-billion in the knowledge economy. Technology and business for development: E E Publishers. https://www.ee.co.za/article/government-to-invest-r78-billi on-in-the-knowledge-economy.html

[17] Hadad, (2017). Knowledge economy: Characteristics and dimensions. Management dynamics in the knowledge economy, 5(2), 203-225.http://dx.doi.org/10.25019/MDKE/ 5.2 .03

[18] Igwenagu, C. (2016). Fundamentals of research methodology and data collection. file://C:/Users/bolab/Do wnloads/FundamentalsofResearchMethodologyandDataCol lection.pdf/ 09/06/2020.

[19] Johnson, D. W., Johnson, R. T., \& Smith, K. A. (2014). Cooperative learning: Improving university instruction by basing practice on validated theory. Journal on Excellence in College Teaching, 25, 85-118.

[20] Kalagbor, D., Nnokam, C., (2015). Principals' and teachers' use of conflict management strategies on secondary students' conflict resolution in Rivers State, Nigeria. Journal of Education and Practice, 6(13), 148-153. https://files.eric.ed.gov/fulltext/EJ1080516.pdf

[21] Kasim, U. (2015). Implementation of group work in the classroom. Lingua, 12(1): 97-106.

[22] Khan, C., \& Chovanec, D. M. (2010). Is participatory action research relevant in the Canadian Workplace? Journal of Contemporary Issues in Education, 5(1), 34-44.

[23] Khanam N, Sahu T, Rao E. V, Kar, S. K., \& Quazi, S. Z. (2017). A study on university student's time management and academic achievement. Int J Community Med Public
Health, 4, 4761-5.

[24] Kim, B. (2001). Social constructivism. In M. Orey (Ed.), Emerging perspectives on learning, teaching, and technology. Retrieved <insert date>, from http://projects.coe.uga.edu/epltt/ Retrieved from http://epltt.coe.uga.edu/index.php?title=Social_Constructivi sm.

[25] Kothari C.R, (2004). Research methodology. New Delhi, India: New Age International Publishers.

[26] Laal, M., \& Laal, M. (2012). Collaborative learning: What is it? Procedia-Social and Behavioral Sciences, 31, 491 - 495. https://doi.org/10.1016/j.sbspro.2011.12.092

[27] Leslie, S. J., Cimpian, A., Meyer, M., \& Freeland, E. (2015). Expectations of brilliance underlie gender distributions across academic disciplines. Science, 347(6219), 262-265. https://doi.org/10.1126/science.1261375

[28] McGregor, D. (1960). The human side of enterprise. New York: McGraw-Hill.

[29] McMahon, M. (1997). Social constructivism and the World Wide Web: A paradigm for learning. Paper presented at the ASCILITE conference. Perth, Australia.

[30] Monk-Turner, E., \& Payne, B. (2005) Addressing issues in group work in the classroom. Journal of Criminal Justice Education, 16 (1), 166-179. https://doi.org/10.1080/105112 5042000333532

[31] Musitha, M. E., \& Mafukata, M. A., (2018), 'Crisis of decolonising education: Curriculum implementation in Limpopo Province of South Africa', Africa's Public Service Delivery and Performance Review 6(1), 1-8. https://doi.org/10.4102/apsdpr.V6i1.179

[32] Nasrullah, S., \& Khan, M. S. (2015). The Impact of time management on students' academic achievements. Journal of Literature, Languages and Linguistics, 11, 66-72.

[33] Ndlovu, M. (2013). Mobilising history for nation-building in South Africa: A decolonial perspective. Yesterday \& Today, 9, 1-12.

[34] Ndlovu-Gatsheni, S. J. (2013). Coloniality of power in postcolonial Africa: Myths of decolonization. United Kingdom: Oxford.

[35] Ndlovu-Gatsheni, S. J. (2015). Decoloniality in Africa. A continuing search for a new world order. Australian Review of African Studies, 36,2: 22-50.

[36] Ngugi wa Thiong'o, (1986). Decolonising the Mind: The politics of language in African literature. Nairobi: Heinemann.

[37] Nordquist, R. (2019). Conversation analysis (CA): Glossary of grammatical and rhetorical terms. https://www.thoughtco .com/what-is-conversation-analysis-ca-1689923. 16/02/2019.

[38] Omodan B. I., \& Tsotetsi, C. T. (2020). Decolonisation of Knowledge Construction in University Classrooms: The Place of Social Constructivism. Journal of Gender, Information and Development in Africa, 9(2), 183-204. https://doi.org/10.31920/2634-3622/2020/9n2a10 
[39] Omodan, B. I. (2019a). Democratic pedagogy in South Africa: A rethinking viewpoint for knowledge construction. Journal of Social Studies Education Research, 10(2), 188-203. https://jsser.org/index.php/jsser/article/view/650/3 75

[40] Omodan, B. I. (2019b). A strategy to enhance crisis management between students and university authorities in Nigeria. PhD thesis, University of the Free State, South Africa.

[41] Omodan, B. I., \& Dube, B. (2020). Towards decolonial agitations in university classrooms: The quest for Afrocentric pedagogy. International Journal of Learning, Teaching and Educational Research, 19(4), 14-28. https://doi.org/10.26803/ijlter.19.4.2

[42] Omodan, B. I. (2020a). The vindication of decoloniality and the reality of COVID-19 as an emergency of unknown in rural universities. International Journal of Sociology of Education, 20, 1-26. http://doi.org/10.17583/rise.2020.5495

[43] Omodan, B. I. (2020b). Combating the imperativeness of modernity in students' unrest: The need to decolonise the mind through ubuntu. International Journal of Higher Education, 9(4), 310-319. https://doi.org/10.5430/ijhe.v9n4 p310

[44] Organisation for Economic Cooperation and Development (OECD). (1996). The knowledge-based economy. Paris: OECD.

[45] Parker, P. S., Smith, S. H., \& Dennison, J. (2014). Decolonising the classroom: Creating and sustaining revolutionary spaces inside the academy. TijdschriftVoorGe nderstudies, 20(3), 233-247.

[46] Peters, M. A. \& Humes, W. (2003). Editorial: Education in the knowledge economy. Policy Futures in Education, 1(1), 1-19. https://journals.sagepub.com/doi/pdf/10.2304/pfie.20 03.1.1.1

[47] Piatt-Jaeger, S. (2011). Unity in the elementary school classroom: Building community through increasing positive social interactions between and among students. Master's thesis, Dominican University of California, USA.

[48] Quan-Baffour, K. P. (2014). Unity in diversity: Ubuntu in the classroom to promote learning among adults from diverse backgrounds. Studies of Tribes and Tribals, 12:2, 239-243. https://doi.org/10.1080/0972639X.2014.11886704

[49] Quijano A. (2000). Coloniality of power, eurocentrism, and Latin America. Nepantla: Views from South, 1(3), 533-580.

[50] Raja, F. U., \& Najmonnisa, D. (2018). Comparing traditional teaching method and experiential teaching method using experimental research. Journal of Education and Educational Development, 5(2), 276-288. https:/files.eric.e d.gov/fulltext/EJ1200262.pdf

[51] Rodney, W., 2012, How Europe underdeveloped Africa, Pambazuka: Dakar.

[52] Scotland, J. (2012). Exploring the philosophical underpinnings of research: Relating ontology and epistemology to the methodology and methods of the scientific, interpretive, and critical research paradigms. English Language Teaching, 5(9), 9-16.https://doi.org/10.5 539/elt.v5n9p9

[53] Scott, D., \& Usher, R. (2011). Researching education. Continuum International Publishing Group: NY.

[54] Tularam, G. N., \& Machise, P. (2018). Traditional vs non-traditional teaching and learning strategies: The case of E-learning! International Journal for Mathematics Teaching and Learning, 19(1), 129-158.

https://www.cimt.org.uk/ijmtl/index.php/IJMTL/article/vie $\mathrm{w} / 21$

[55] Zuber-Skerritt, O. (2015). Conceptual framework. In O. Zuber-Skerritt, M. Fletcher, \& J. Kearney (Eds.), Professional learning in higher education and communities: Towards a new vision of action research (pp. 1-37). London, England: Palgrave McMillan. 